\title{
PERLAKUAN KHUSUS TERHADAP NARAPIDANA LANJUT USIA DALAM PENINGKATAN KESEJAHTERAAN DAN KESEHATAN DI LEMBAGA PEMASYARAKATAN
}

Elang Suryandaru

Teknik Pemasyarakatan, Politeknik Ilmu Pemasyarakatan, elangsuryandaru@gmail.com

\begin{abstract}
Being elder is a phase that everybody will deal with it, indicated by the ability of physically and mentally decreased. The physical frequency that starts to weaken and get sick causes it to become unproductive and even dependent on others. Elderly people are categorized as vulnerable groups that must get special treatments, especially the elderly prisoner who serve a sentence in the prison. It is something that must be considered in fulfilling the human rights of elderly prisoners, both in terms of services and infrastructure needed. This research aim is to see what the implementation of the treatments of the elderly prisoners in the Correctional Database Systemis like. Especially, in the maintenance and the improvement of their well-being and health status, with the purpose of not adding to the burden that must be taken away from their rights of freedom and the physical condition of illness suffered as an elderly person. According to the data from Correctional Database SystemDatabase System on February 2020, the numbers of all elderly prisoners in the Indonesian Correctional Database Systemwas 3.555 prisoners, at least $2 \%$ of the total prisoners throughout Indonesia. With this research, it is hoped that the placement of elderly prisoners and the improvement of their well-being and health status can be carried out as well as possible in order to fulfill the rights of prisoners.
\end{abstract}

\section{ARTICLE INFO}

\section{Keywords:}

Elderly; Prisoner, Health;

Treatment

\section{Cite this paper:}

Suryandaru, E. (2021).

Perlakuan Khusus

Terhadap Narapidana

Lanjut Usia Dalam

Peningkatan Kesejahteraan Dan Kesehatan Di Lembaga

Pemasyarakatan. Widya Yuridika: Jurnal Hukum, $4(2)$.

\section{Scope Article}

Law and Society

\section{PENDAHULUAN}

Pemberian hak narapidana dalam pemenuhan pelayanan kesehatan kewajiban yang sudah di atur dalam Undang-Undang Nomor 12 Tahun 1995 tentang Pemasyarakatan pasal 14 butir d, "mendapatkan pelayanan kesehatan dan makanan yang layak". Hak atas pelayanan kesehatan harus dijunjung tinggi dan dihormati serta diwujudkan. Dasar - dasar mengenai pemberian pemberian hak kepada narapidana untuk dapat memperoleh layanan kesehatan yaitu bahwa penjatuhan atau pemberian hukuman pidana penjara oleh hakim itu hanyalah pembatasan kebebasan bergerak dan hak kemerdekaan bergerak (hilang kemerdekaan) saja. Hubungan diantara pelayanan kesehatan dan hukum itu akan terlihat jelas di dalam hukum kesehatan dimana hukum kesehatan itu bisa dirumuskan sebagai suatu kesatuan dari peraturan hukum yang telah diatur dan secara langsung berhubungan dengan pelayanan kesehatan (Ronny. A. Sinlae, 2016). Pelayanan kesehatan kepada narapidana memiliki 2 bentuk yaitu, pelayanan secara umum yang artinya diberikan kepada narapidana seperti biasanya yang sesuai dengan program pelayanan kesehatan yang ada di Lapas dan berupa sarana prasarana pelayanan yang khusus sesuai jenis penyakit. Untuk 
memperlancar dalam pelaksanaan pelayanan kesehatan di UPT Lapas dan Rutan, melalui adanya Surat Keputusan Direktur Jenderal Pemasyarakatan Nomor: E.03.PP.02.10 tahun 2003 ditetapkannya standar pelayanan minimal pelayanan kesehatan narapidana di Lembaga Pemasyarakatan.

Pelayanan kesehatan secara khusus juga harus dipenuhi bagi narapidana yang termasuk kelompok rentan, lanjut usia. Lanjut usia merupakan golongan yang lemah, harus diberikan pelayanan dan perawatan khusus karena telah mengalami kemunduran mental dan fisik. Narapidana lanjut usia memiliki hak secara khusus yang diatur di UU No 32 tahun 2018 tentang Perlakuan Bagi Tahanan dan Narapidana Lanjut Usia pasal 3, salah satu butir dari pasal tersebut "pemeliharaan dan peningkatan derajat kesehatan". Penyakit yang diderita karena penuaan oleh narapidana lanjut usia menjadikan beban atau hukuman tambahan dalam menjalani masa pidana, maka diberikan bentuk pelayanan kesehatan dan sarana prasara secara khusus. Untuk membantu pelayanan kesehatan yang secara khusus untuk narapidana lansia dibentuk tim medis khusus dalam penanganannya dapat juga dibantu pihak luar lapas dan dapat dilakukan juga di luar Lapas sesuai dengan peraturan di dalam perundang undangan. Dalam berupaya peningkatan derajat kesehatan bagi narapidana lansia juga pemenuhan kualitas makanan dan gizi yang baik.

Pelayanan kesehatan terhadap narapidana lansia dilaksanakan menurut standar pelayanan kesehatan pemasyarakatan, mekasime awalnya dilakukannnya skrining atau pemeriksaan kesehatan di poliklinik kemudian apabila mengidap penyakit yang menular di tempatkan terpisah dari narapidana lainnya. Untuk mendapatkan perhatian perawan yang lebih dilakukan pemeriksaan rutin sebulan sekali, karena keterbatasan tenaga medis dan obat obatan bekerja sama dengan dinas kesehatan sekitar lapas. Untuk penempatan dan perlakuan khusus narapidana lansia juga sudah blok khusus lansia di Lapas Kelas IIA Serang sebagai lapas percontohan untuk perlakuan narapidana lansia. Direktorat Jenderal Pemasyarakatan juga mengusulkan untuk disahkannya Jakarta Rules yang mengatur tentang perlakuan narapidana lanjut usia.

Masih ada kelebihan dan kekurangan untuk upaya perwujudan peningkatan derajat kesehatan bagi narapidana lansia. Narapidana lansia masih belum tahu tentang apa itu gerontologi atau penyakit yang akan dialami pada fase lanjut usia, belum adanya penyuluhan tentang hal tersebut. Belum dipisahkannya antara narapidana yang masih muda dengan narapidana lanjut usia secara menyeluruh karena terkendala masalah di lapas yang kelebihan kapasitas dan perbandingan jumlah narapidana dengan petugas yang masih jauh. Kurangnya sumber daya manusia dan pengetahuan petugas untuk menangani hal perlakuan khusus narapidana lanjut usia.

Penelitian ini memberikan solusi untuk permasalahan yang terjadi selama ini. Solusi yang dapat diterapkan yaitu pemberian penyuluahan kepada lansia tentang apa saja yang akan dialami pada fase lanjut usia sehingga mendapatkan perhatian khusus. Kemudian penambahan petugas medis dan menjalankan pemerikasaan secara rutin sebulan sekali sehingga dapat memberikan hasil yang maksimal mengahdai masalah yang terjadi di usia lanjut usia. Selain itu, bekerja sama dengan lembaga sosial dan kesehatan dalam menangani pemasalah lanjut usia, sehingga penanganan yang cepat dan tepat pada saat terjadi hal yang tidak diinginkan terhadap narapidana lansia.

\section{METODE}

Penelitian dilaksanakan di Lembaga Pemasyarakatan Kelas II A Kendal, waktu penelitian pada bulan Juni sampai Juli 2020. Dalam menentukan lokasi untuk penelitian cara terbaik yang harus ditempuh dengan jalan mempertimbangkan teori subtantive dan menjajaki keadaan di lapangan untuk mencari kesesuaian dengan kenyataan yang ada di lapangan (Moeleong, 2000:86). Lokasi penelitian diambil berdasarkan data jumlah narapidana yang termasuk dalam kelompok rentan yaitu lanjut usia. 
Jenis penelitian yang digunakan oleh peneliti adalah Penelitian Kualitatif dengan menggunakan metode penelitian triangulasi. Pada penelitian kualitatif ini, pengumpulan data menggunakan beberapa metode, yaitu wawancara, observasi, dan menggunakan kajian literatur lainnya. Penelitian kualitatif digunakan untuk menggali tema/ide yang muncul terkait dengan pemenuhan pemeliharaan dan derajat kesehatan terhadap narapidana di lembaga pemasyarakatan. Kemudian, tema tersebut akan dijadikan alat pengumpulan data untuk melakukan survey.

Dalam penelitian ini peneliti dapat mengambil populasi dari semua narapidnaan lanjut usia dan petugas kesehatan yang berada dan bertugas di Lapas Kelas IIb Kendal. Narasumber yang di pilih oleh peneliti untuk mempermudah proses penelitian dalam mencari informasi abru dan dibutuhkan. Penentuan Informan atau narasumber di peneelitian ini menggunnakan teknik atau cara purposive sampling, yang dimana pemilihan dilaksanakan secara sengaja atau secara pilihan oleh peneliti berdasarkan keriterian yang ada dan telah ditentukan dan diteteapkan oleh peneliti yang berdasarkan tujuan penelitian sudah di tentukan.

\section{HASIL DAN PEMBAHASAN}

Dalam pelaksanaannya, Pemerintah Indonesia khusunya Kementerian Hukum dan HAM RI sudah dapat berperan secara aktif didalam memperhatikan kelangsukan kehidupan para narapidana lanjut usia, didalam bidang kesehatan maupun di bidang sosial, dapat dibuktikan dengan adanya berbagai peraturan, diantaranya :

\section{Peraturan tentang HAM}

\begin{tabular}{|l|l|l|}
\hline No & JENIS PERATURAN & TENTANG \\
\hline $\mathbf{1}$ & $\begin{array}{l}\text { SMR / Standard Minimum Rules of } \\
\text { Prisoners }\end{array}$ & $\begin{array}{l}\text { Standar pelaksanaan operasional } \\
\text { jawatan kepenjaraan seluruh dunia }\end{array}$ \\
\hline $\mathbf{2}$ & $\begin{array}{l}\text { Undang-Undang Nomor 13 Tahun 1998 } \\
\text { Kesejahteraan Lanjut Usia }\end{array}$ \\
\hline $\mathbf{3}$ & $\begin{array}{l}\text { Peraturan Pemerintah Nomor 43 Tahun } \\
\text { 2004 }\end{array}$ & $\begin{array}{l}\text { Pelaksanaan Upaya Peningkatan } \\
\text { Kesejahteraan Sosial Lanjut Usia }\end{array}$ \\
\hline $\mathbf{4}$ & Undang-Undang Nomor 36 Tahun 2009 & Kesehatan \\
\hline $\mathbf{5}$ & $\begin{array}{l}\text { Peraturan Menteri Sosial Nomor 19 } \\
\text { Tahun 2012 }\end{array}$ & $\begin{array}{l}\text { Pedoman Pelayanan Sosial Lanjut } \\
\text { Usia }\end{array}$ \\
\hline $\mathbf{6}$ & $\begin{array}{l}\text { Peraturan Menteri Hukum dan HAM } \\
\text { Nomor 32 Tahun 2018 }\end{array}$ & $\begin{array}{l}\text { Perlakuan Bagi Tahanan dan } \\
\text { Narapidana Lanjut Usia }\end{array}$ \\
\hline
\end{tabular}

Sumber : data pengkajian oleh penulis

\section{A. Kondisi Narapidana Usia Lanjut di Lembaga Pemasyarakatan}

Peraturan yang telah diterbitkan oleh Kementerian Hukum dan HAM yaitu Permenkumham No 18 Tahun 2018 tentang Perlakuan Terhadap Tahanan dan Narapidana Lanjut Usia, pada saat ini belum dilaksanakan dengan baik dan optimal. Itu dikarenakan belum adanya juklak atau petunjuk pelaksanaan dari Direktorat Jendral Pemasyarakatan

Sejak peraturan tersebut dikeluarkan, selama ini pelaksanaannya tidak secara merata yang ada dalam kandungan peraturan tersebut. Pelaksanaan perlakuan ini sudah dilaksanakan dan diterapkan oleh beberapa UPT Pemasyarakatan, yakni : Lapas Kelas IIA Batam, Lapas Kelas IIA Serang, Lapas Kelas IIA Cilegon, Lapas Kelas IIA Pekanbaru. 
Hasil survei di Lembaga Pemasyarakatan Kelas IIA Kendal, saat ini belum menerapkan pelakuan khusus terhadap narapidana lanjut usia secara optimal. Informan MK menyatakan bahwa "Lapas kendal sebenarnya sudah mencoba untuk memisahkan fasilitas hunian dengan narapidana lainnya tetapi karena kapasitas hunian yang ada tidak sebanding dengan jumlah Warga Binaan." Hal ini menujukan pelaksanaan yang belum maksimal dari Permenkumham Nomor 32 Tahun 2018 tentang Perlakuan Terhadap Tahanan dan Narapidana Lanjut Usia, belum meratanya pemisahan narapidana lansia dengan lainnya sehingga seperti ada deskriminasi untuk yang belum dipisahkan. Padahal memang dikarenakan permasalahan sarana prasana yang kurang memadahi dan masalah overcapacity.

Selain itu dalam pemenuhan dan pemeliharaan kesehatan bagi narapidan umum(bukan lansia) saja masih belum maksimal dikarenakan tidak adanya petugas kesehatan sama sekali di Lapas, hanya saja digantikan oleh petugas yang pernah mengikuti pendidikan kesehatan tetapi tidak lulus. Mengatasi hal tersebut pihak poliklinik bekerjasama dengan dokter di Pukesmas Kendal I yang datang setiap hari Rabu. Meskipun sedikit membantu, tetapi kurang optimal dalam perlakuan khusus menangani lansia karena dokter juga menangani terhadap narapidana umumnya. Terdapat juga narapidana yang kondisinya kurang memungkinkan menjalani masa pidana atau masa hukuman dikarenakan kondisi kesehatannya yang harus sangat diperhatikan, adanya narapidana yang mengalami kondisi stroke ringan yang disebabkan oleh tekanan darah yang tinggi dan menu makan yang tidak sesuai dengan kondisi kesehatan.

Permasalahan yang sering dialami oleh narapidanan lanjut usia di Lapas yang seharusnya mendapatkan perlakuan khusus yang lebih baik dan lebih optimal secara penyediaan fasilitas maupun pembinaan, Antara lain :

a) Pemisahan Hunian

Pemisahan Hunian yang dilaksanakan di lembaga pemasyarakatan atau rumah tahanan dalam rangka untuk menghemat biaya karena biaya yang dikeluarkan untuk sektor keamanan atau tingkat risiko jauh lebih kecil daripada Lembaga Pemasyarakatan atau rumah tahanan yang yang disamakan dunianya dengan lansia dan yang dewasa. Tingkat risiko yang dihadapi oleh para narapidana Lanjut Usia di dalam hunian jauh lebih kecil untuk tertular penyakit apabila pemisahan hunian dapat dilaksanakan dan oleh karena itu dari tingkat penyebaran penyakit yang rendah tingkat kesembuhan atau pulihnya dari penyakit tersebut juga jauh lebih meningkat dan jauh lebih cepat karena dari sektor hunian juga di khusus kan untuk para lansia dan pemenuhan gizi dan perawatan sudah difokuskan untuk para narapidana yang sudah lanjut usia, pasti menjadi hal yang wajar apabila suatu saat narapidana lansia memiliki keluhan keluhan dalam kesehatannya karena usia yang sudah lanjut. pemisahan Hunian yang berbeda dapat juga mempermudah dalam pemenuhan hak-hak untuk para narapidana lanjut usia khususnya bagi tahanan dan narapidana lansia. namun berbeda dengan treatment yang dilaksanakan oleh negara India yang menjadi salah satu negara dengan jumlah penduduk yang sangat besar di dunia yang di mana menganjurkan pemisahan hunian di suatu lembaga pemasyarakatan untuk narapidana yang sudah menginjak usia lanjut Oleh karena itu beberapa alasan yang menjadi penghematan biaya perawatan menjadi faktor utama dalam pemisahan hunian antara narapidana dewasa dengan narapidana yang sudah lanjut usia, Selain itu adapun kemudahan dalam pencatatan dan pemerhatian dalam memantau kesehatan narapidana usia, kemudahan dalam bentuk memberikan pembinaan yang dikhususkan untuk narapidana lanjut usia dan juga tingkat keamanan yang diukur sedemikian rupa agar cocok untuk para narapidana lansia. 
Dari uraian di atas yang dilihat dari memperhatikan risiko yang mungkin akan terjadi Dirjen PAS atau Direktorat Jenderal Pemasyarakatan menempuh jalan atau mengambil jalan untuk memberikan treatment dengan cara cara memisahkan blok blok hunian bagi para narapidana Lanjut Usia dan dewasa alasan ini diambil karena untuk penghematan biaya dan tidak untuk membangun Lapas atau rutan baru karena untuk membangun Lapas atau rutan baru memerlukan biaya yang sangat tinggi.

b) Pemenuhan Fasilitas Sarana dan Prasarana yang Khusus

Pemenuhan sarana dan prasarana yang ditujukan kepada narapidana lanjut usia harus diperhatikan dalam pengadaannya di suatu UPT Lapas atau Rutan sarana prasarana yang khusus yang harus disediakan untuk para tahanan dan narapidana Lanjut Usia diantaranya seperti : Tongkat untuk berjalan, Kursi Roda, Jalan yang tidak licin, Toilet duduk, Akses menuju atau dari dan ke dalam bangunan, Tiang pada tangga utuk pegangan, kondisi dinding kamarmandi yang layak bagi lansia, Alat peringatan darurat atau Alarm atau bisa juga sinyal, Poliesehatan atau Poliklinik yang tempatnya berdekatan dengan blok hunian narapidana, sarana ibadah yang layak dan yang berada dalam blok hunian agar para narapidana dan tahanan tidak terlalu jauh dalam menempuh jarak, dan juga adanya perpustakaan dan juga Saung untuk ekskresi selama menjalani pembinaan di Lapas atau rutan.

c) Makanan Khusus Lansia

Dalam perawatan narapidana Yudisial perlu juga diperhatikan dalam sektor pemenuhan gizi, pemenuhan gizi yang diberikan Terhadap narapidana dan tahanan Lanjut Usia saat ini masih disamakan dengan narapidana dewasa atau narapidana yang lain pada lapas atau rutan di Indonesia . Padahal kebutuhan gizi pada seseorang yang menginjak usia dewasa dengan seseorang yang menginjak usia lanjut usia itu memerlukan pemenuhan gizi yang berbeda dalam takaran kategori gizinya yang dihitung per hari. pemenuhan gizi dari setiap kategori dapat dilihat pada tabel standar gizi berikut ini :

\section{Standar Kebutuhan Gizi}

\begin{tabular}{|c|c|c|}
\hline No & Kategori & Gizi Perhari \\
\hline 1. & Dewasa & $\begin{array}{l}\text { Energi: } 2250 \mathrm{kkal} \\
\text { Protein: } 62 \mathrm{gr} \\
\text { Karbohidrat: } 380 \mathrm{gr} \\
\text { Lemak: } 70 \mathrm{gr} \\
\text { Serat :32gr } \\
\text { Air: } 2600 \mathrm{ml}\end{array}$ \\
\hline 2. & Lanjut Usia & $\begin{array}{l}\text { Energi: } 1800 \mathrm{kkal} \\
\text { Protein: } 60 \mathrm{gr} \\
\text { Karbohidrat: } 300 \mathrm{gr} \\
\text { Lemak: } 50 \mathrm{gr} \\
\text { Serat: } 25 \mathrm{gr} \\
\text { Air: } 1900 \mathrm{ml}\end{array}$ \\
\hline
\end{tabular}

Sumber : Permenkes No 73 Tahun 2013

Dari tabel diatas dapat dilihat kebutuhan gizi antara kategori dewasa dengan kategori Lanjut Usia standar gizi tersebut dirancang dan ditentukan oleh 
menteri kesehatan pada Peraturan Menteri Kesehatan Nomor 73 tahun 2013. gizi yang diberikan kepada untuk tahanan dan narapidana pada lembaga pemasyarakatan yang didalamnya ada narapidana dewasa standar gizi adalah sebagai berikut yaitu mengandung Energi 2250 Kkal, Protein 62 gr, Lemak 70 gr, Karbohidrat 380 gr dan air 2600 ml, Kebutuhan gizi ini sangat berbeda dibandingkan kebutuhan yang harus diterima oleh para tahanan atau narapidana lanjut usia di dalam Lapas atau rutan pemenuhan gizi pada narapidana dan tahanan lanjut usia hanyalah besar antara lain : energi 1800kkal dengan jumlah Protein 60 gr, karbohidrat 300 gr, Lemak50 gr, serat 25 gr, dan air 1900 ml.Dengan demikian dari data ini kita bisa lihat bahwa di lapangan pemenuhan gizi di Lapas atau Rutan khususnya dalam hal makanan yang disediakan tidak dilakukan pemisahan dalam pengelolaan bahan makanan yang ditunjukkan kepada narapidana yang ada di Lapas atau Rutan tersebut oleh karena itu terjadilah ketidak sesuaian porsi makanan atau pemenuhan gizi yang diberikan kepada narapidana baik itu narapidana dewasa dan narapidana lansia dari makanan yang diberikan setiap harinya.

Hal ini bisa dan dapat terjadi dikarenakan dalam suatu pemberian asupan makanan tidak diperhatikan hanya mempertimbangkan asupan gizi Semata namun ada juga yang dipengaruhi oleh kondisi G seperti depresi yang dialami, jumlah dan kondisi kesehatan gigi dan gangguan-gangguan yang terjadi pada gigi, penggunaan obat-obatan yang diminum, Serta adanya rasa sakit yang sedang dideritanya, serta dengan adanya dukungan sosial yang meliputi kunjungan dan cita rasa makanan yang ada..(Amran et al., 2010)

d) Perawata Pelayanan Kesehatan Khusus pada Narapidana Lansia

Salah satu inti harus diperhatikan lagi adalah perawatan kesehatan khusus bagi lanjut usia atau lansia dapat dilihat dari kondisi real atau nyata yang ada di lapangan dengan kondisi ideal sesuai peraturan yang seharusnya Sesuai dengan amanat Nomor 32 tahun 2018, di mana Di dalam amanat tersebut adalah masih banyaknya persamaan perlakuan perawatan kesehatan bagi narapidana dewasa dan narapidana lansia di mana perawatan bagi narapidana lansia jelas-jelas sangat berbeda bagi narapidana dewasa yang dilihat dari aspek medis dan kedokteran yang ada. hal ini bisa terjadi dikarenakan belum adanya pemisahan blok hunian bagi para narapidana lansia dan juga narapidana dewasa, Dapat kita lihat referensi atau salah satu sumber yang ada di Pati jompo di salah satu Indonesia yang dimana perlakuan perawatan kesehatan bagi para seseorang yang sudah menginjak usia lanjut perlakuan khusus terhadap seseorang yang sudah memenuhi usia lanjut harus dibedakan dan diberikan perawatan yang khusus berikut ini dapat dilihat perbandingan data dari pati jompo dan lapas di indonesia :

\section{Perbandinagan Cara Perawatan}

\begin{tabular}{|l|l|l|}
\hline No & Panti Jompo & Lapas \\
\hline 1 & Dapat bisa bergerak bebas & Pergerakan dibatasi oleh kebijakan \\
\hline 2 & Rekreasi mudan dan terpenuhi & Rekreasi tidak ada \\
\hline 3 & Dirawat oleh tenaga ahli & Tidak ada Perawatan \\
\hline 4 & $\begin{array}{l}\text { Layanan Kesehatan dapat mudah } \\
\text { didapatkan }\end{array}$ & $\begin{array}{l}\text { Layanan Kesehatan kurang lengkap } \\
\text { dan lama penangananya }\end{array}$ \\
\hline
\end{tabular}


Sumber: data diolah dari jurnal tinjauan gerontologi dalam lapas

Dari data yang ada dapat dilihat kebutuhan yang harusnya didapat oleh seseorang yang sudah menginjak Lanjut Usia di suatu batik jumput di lapan beda Perlak kuat terutama dalam jembatan mulai dari kesehatan harian serta sampai dengan makanan yang diberikan harus berbeda porsinya dengan naratif dan lanjut usia dengan narapidana dewasa. ketanggapan dalam menangani keluhan-keluhan yang dihadapi oleh narapidana di usia juga harus diperhatikan lebih baik Apabila dari pelayanan kesehatan mengetahui apa keluhan-keluhan yang dihadapi dengan lebih cepat dapat mencegah terjadinya penyakit penyakit yang lebih parah atau dapat mencegah narapidana banjir usia tersebut mendapatkan gejala yang lebih parah sehingga tingkat resiko kematian dan penyakit yang kronis dapat dihindari. Yang menjadi masalah adalah salah satunya yaitu tingkat penghuni Lembaga Pemasyarakatan atau rumah tahanan di Indonesia sudah mencapai batas maksimum bahkan melebihi Oleh karena itu pemenuhan tenaga kesehatan juga harus diimbangi dengan adanya bumi yang banyak.

Untuk menciptakan perawatan kesehatan yang optimal dan efisien terdapat beberapa hal yang harus dipenuhi antara lain:

a) Akses

b) Adanya tenaga ahli dalam perawatan

c) Adanya niat atau persetujuan dari pasien unutk dirawat

d) Tersedianya program program kesehatan dan sarana kesehatan.

e) Adanya Materi . (Medicine, 1989)

Dari 5 hal yang disebutkan di atas masih ada kekurangan yang harus dilengkapi di Lapas atau Rutan di seluruh Indonesia kendala-kendala yang belum terpenuhi biasanya yaitu terkait dengan jumlah tenaga dan juga jumlah anggaran yang tidak sesuai aturan lapangan dan jumlah anggaran tersebut sudah habis dengan keperluan yang lain seperti keperluan makanan bagi narapidana sudah menghabiskan banyak sekali anggaran yang disediakan dari pemerintah Pemasyarakatan . Terlepas dari masalah yang ada pemenuhan kesehatan harus terus ditingkatkan Seiring berjalannya waktu untuk mem penuh perawatan kesehatan yang lebih optimal bagi warga Lanjut Usia.

e) Pembinaan Khusus Lansia

Dalam memebrikan pembinaan pada narapidana lanjut usia para petugas pemasayarakatan yang beristeraksilangsung dan secara langsung memeberikan pembinaan kepada narapidanan harus dapat menyadarkan narapidanan tersebut bahwa apa yang di lakukannya selama ini adalah perbuatan salah dan perbuatan yang melangar hukum, sehingga narapidana akan menyadari akan kesalahan yang telah di perbuatnya. Agar para narapidana dapat sadar akan perbuatan yang telah dilakukannya narapidana di berikan pembinaan yang di mana pembinaan tersebut harus sesuai dengan kondisi fisik yang di alami oleh narapidana lansia tersebut, sehingga pembinaan yang di berikan akan tepat sarannya dan lebih efektif untuk hasilnya, selain itu kegiatan pembinaan yang diberikan apabila sesuai dengan kondisi narapidana tersbut narapidana itu akan melaksanaknnya dengan sepenuh hati dan tanpa tekanan dan paksaan. Dengan demiian narapidana lanjut usia tersebut dapat memulihkan kehidupan, kesetuan hidup, dan Penghidupan.

Proses Pembinaan yang seharusnya diberikan dan dilaksanakan untuk para narapidana lanjut usia adalah pembinaan dalam bentuk pemberian intervensi yang di mana campur tangan dari pihak lembaga atau salah satu pihak dapat memberikan efek yang berarti kepada narapidana lanjut usia tersebut. 


\section{B. Karakteristik serta Intervensi Para Tahanan dan Narapidana Usia Lanjut di Lembaga Pemasyarakatan}

Dari wawancara yang telah dilakukan oleh peneliti dengan para narasumber yang ada dapat diketahui bahwa para narapidana lansia cenderung melakukan kejahatan yang di mana kejahatan tersebut merupaka kejahatan umum seperti kejahatan seksual, pelecehan seksual, pembunuhan, kasus kekerasan. Dalam membrikan pembinaan kepada para narapidana lansia harus memberika pembinaan yan sesuai dengan jenis kejahantan yeng mereka lakukan agar pembinaan tersebut berjalan efektif yang mendapatkan hasil yang baik. Dilihat dari tingkat kejahatan yang dilakukan oleh para merah dan tahan lama dan tidak mempunyai suatu karakteristik yang dapat dipahami oleh berbagai petugas Pemasyarakatan Bagaimana bisa dilihat sebagai berikut (Beck et al., 2015) :

a. Kesulitan dalam malaksanakan beradaptasi saat awal masuk dalam penjara.

b. Besar Kemungkinan di asingkan dari keluarga narapidanan dan tahanan itu sendiri dikarenakan kejahatan yang pernah dilakukannya.

c. Mendapatan penekanan Psikologis seperti batin

d. Memiliki rasa cemas dan bersalah akan perbuatan yang telah di lakukannya.

e. Memiliki Rasa kahawatir yang tinggi karna akan berakhir hidupnya didalam penjara.

f. Bisa melakukan isolasi diri atau menyendiri dari kehidupan disekitarnya yang disebabkan kurnagnya rasa social yang ada di dalam sel penjara.

g. Resiko melakukan Bunuh diri yang cenderung lebih besar karna frustasi atau kesehatan mental yang kurang di dalam penjara

h. Menginginkan fasilitas dan pelayanan kesehatan yang lebih baik dan membandingkannya di luar tembok penjara.

Dari Karakteristik yang telah dijelaskan Bupati Intinya kita sebagai petugas Pemasyarakatan harus mempunyai kelakuan dan memberikan perlakuan dan kelainan yang intervensi atas penggunaan yang tepat kepada narapidana lansia. Baik Intervensi yang bersifat multi intervensi atau intervensi komponen tunggal, Intervensi ini juga sangat membutuhkan anggaran atau biaya yang diperlukan dalam pelaksanaan dan operasionalnya di mana biaya atau anggaran yang diperlukan besar kecilnya tergantung pada kebutuhan dari mana yang lebih mendesak dan lebih kompleks dalam penanganannya, karena pada dasarnya kebutuhan setiap individu narapidana atau tahanan yang ada itu sangat berbeda, yang didasarkan pada Ada apa masalah yang dihadapinya. Walaupun demikian harus mengeluarkan anggaran yang tinggi dan besar hal ini harus menjadi prioritas utama atau prioritas yang tinggi dalam pelaksanaannya. tahapan intervensi supaya dapat berjalan lebih optimal tinggal Suatu kondisi dari setiap orang tekanan dan narapidana lanjut usia sebagai berikut (Richard Schulz , PhD George Maddox \& M. Powel l Lawton, 1998) :

a. Pengumpulan Data Data dan Implemtasi Terhadap Perawatan.

Implementasi harus memiliki beberapa indicator didalamnya:

i. Pemberian Obat Obatan

ii. Penerimaan Pengobatan

iii. Perlakuan terhadap perawatan (Ibrahim \& Sidani, 2015)

Dari unsur-unsur yang telah disebutkan termasuk dalam pemberian obat obatan dan pengobatan dengan pengawasan terhadap panntauan perkembangan pemberian intervensi itu harus dilakukan dengan seksama dan memerlukan pengawasan extra. setelah intervensi diberikan pada narapidana dan tahanan terdapat beberapa indikator yang dapat menyatakan bahwa lansia menerima pengobatan yang telah diberikan dengan baik. Apa yang dimiliki cukup sulit untuk dinilai dikarenakan data yang harus dibutuhkan bukan saja pada waktu lansia menjadi intervensi tetapi dibutuhkan juga data keseharian mulai dari kegiatan sehari-hari dan pola perilaku ditunjukkan diluar waktu intervensi pada narapidana dan tahanan tersebut yang di 
mana pada akhirnya bisa menjawab semua implementasi dalam perawatan dengan menggunakan indikator dan kepatuhan yang ditujuhkan oleh narapidana dan tahanan Pancasila tersebut

b. Pemahaman Dalam Mekanisme Pelaksanaan.

Untuk memahami maksut yang dinding di tujukan kepada tujuan intrvensi secara keseluruhan diperlukan suatu hasil dari studi penelitian yang sudah ada yang dimana akan menjadi tindakan pada suatu individu atau di dalam lingkunagan disekitarnya akan berpengaruh terhadap tindakan yang ada. Yang menjadi topic utama adalah untuk dapat memahami mengapa dan bagaimana suatu hasilyang ingin dicapai dapat terwujud. .

d) Penggunakan Jangka Waktu dan Hasil Dari Proses Intervensi.

Setelah tahap tahap intervensi jelaskan sangat lancar bisa mendapatkan satu hasil yang positif, sebagian besar keberhasilan yang didapatkan tidak dinilai dari seberapa lama keberhasilan itu bertahan, mulai dari beberapa minggu sampai dengan beberapa bulan bahkan hingga tahun lamanya. Dengan demikian keberhasilan tersebut dapat dinilai dari berapa lama yang yang ditempuh itu yang singkat atau panjang. suatu keberhasilan dapat bertahan dengan lama dapat menggunakan cara pemberia dosis intervensi yang primer telah selesai dan narapidana atau tahanan yang yang mencapai kriteria yang diukur dari hasil utama. dari cara ini dapat memberikan pengobatan dengan waktu yang cukup lama dengan biaya yang lebih efisien atau yang lebih rendah, hal ini adalah suatu prioritas yang tinggi dari intervensi itu sendiri. Melaksanakan suatu pembinaan terdapat salah satu rekomendasi mengenai suatu program pembinaan yang didapatkan dari tawaran untuk diterapkan di suatu lembaga kemasyarakatan yang disebut sebagai SSLP atau Structure Senior Living Program. (Udhayakmar \& Ponnuswami, 2013)Mulai dikerjakan pada tahun 2004 di Nevada, dengan tujuan yang utama menyetir kegiatan harian yang mencakup dorongan pribadi, mental, emosional, spiritual, dan pertumbuhan pada orang tersebut. Dengan peserta keseluruhannya adalah para narapidana dan tahanan lanjut usia yang usianya diatas 60 tahun lebih.

Dalam pelaksanaannya ada beberapa aturan yang diberikan yaitu peserta programpembinaan harus tujuh mendatangani perjanjian program dan dan diharuskan mengikuti seluruh rangkaian kegiatan tersebut dari awal sampai akhir. Dengan aturan tersebut ialah sebagai berikut:

a. Pengisian Absen setiap harinya dengan memperhatikan secara seksama program hariannya

b. Tetap menjaga kebersihan dalam diri pribadi meliputi kebersihan luar badan dan dalam badan

c. Selalu menyelesaikan absen dan lembar tugasa harian dan selesaikan SSLP

d. Selalu menjaga perwatan dan fasilitas SSLP

Setelah peserta setuju dan mengikuti seluruh program yang telah disediakan, selanjutnya adalah program program yang dijalankan dan dianggap lebih efektif dalam meningkatkan kualitas hidup narapidana dan tahanan tersebut secara keseluruhan yang di mana program-program itu meliputi :

a) Diberikan program pelatihanberupa pelatihan keterampilan untuk kelangsungan hidup seperti membuat rencana pola makan dengan menggunakan anggaran yang ada, diberika pelatihan memasak, mengatur waktu sehari hari, dan lain lain.

b) Mengapresiasi kualitas audio seperti music dengan koleksi seperti lagu lagu dan audio lainnya yang secara komprehensif seperti adanya CD dan DVD.

c) Kelompok Musik yaitu membentuk suatu kelompok atau group atau suatu paduan suara untuk memebrikan dorngan terhadap keterlibatan sosial, dan akan ditampilkan juga secara rutin setiap minggunya untuk hiburan didalam tempat pembinaan. 
d) Penghargaan seni yang di amnaa program ini dilakukan dengan menggunakan ketrampilan seni tiap narapidanan bisa berupa melukis menggunaka pensil, cat minyal, arang, dan pastel dan melukis menhgunakan akrilik

e) Mengolah manik manik yang dimana memiliki tujuan yang akan meningkatkan funsi kognitif serta peningkatan dalam ketangkasan manual dengan kegiatan kegiatan yang rutin dalam pelatihan pembuatan karya kerajinan yang terbuat dari kumpulan manik manik seperti gelang tanggan, kalung, gelang kepala, atau benda seni lainnya yang bersifat dekoratif

f) Program kerajinan tangan, program ini bisa beruma pembuatan karya dari tanah liat atau pun dari bahan bahan bekas yang ada dikehidupan sehari hari

g) Kegiatan kebugaran olahraga fisik. Program kebugaran dan olahraga fisik mencakup berbagau pelatihan seperti senam aerobik setiap minggunya, permainan olahraga seperti voli, tenis meja, basket, atau futsal.

h) Kelompok menulis. Yaitu Programm yang dilakanakan untuk para narapidanan yang menjalani hukuman yang relatif lama dan seumur hidup unutk mempersiapkan diri baik secara mental, fisik, emosional, spiritual sampai akhir kehidupannya.

i) Kebugaran fisik secara Khusus. Kegiatan ini ialah suatu kegiatan olahraga bagi narapidanan yang mengalami keterbatasan tubuh atau disabelitas dengan kursi roda atau kesulitasn dalam melakukan aktifitas sehari hari.

\section{Pembinaan Narapidana Lanjut Usia di Lemabaga Pemasyarakatan}

Pada kegiatan pembinaan di lemabaga pemasyarakatan di lakukan dengan cara dan pola yang di tetntuan dengan strategi dan pertimbanagan yang matang agar proses pembinaan kepada narapidana lanjut usia dapat berjalan efektif dan memiliki hasil yang maksimal. Serta pengulangan tidnak kejahatan semakin menurun apabila di lakukan proses pembinaan yang efektif dan tepat. Metode pembinaan dilakukan dengan cara sebagai berikut ( Supriyono, 2020 ) :

a. Pembinaan dengan cara interaksi langsung yang bersifat kekeluargaan Antara petugas dan narpaidana

b. Pembinaan yang bersifat persuasive yang dimana yang ditujukan untuk memeprbaiki pola tingkah laku melalui, contoh yang diberikan dan keteladanan yang diberikan oleh para petugas

c. Penempatan narapidana sebagai seorang manusia yang memiliki potensi yang dapat menjaga kehormatan harga diri dan menumbuhkannya serta dengan adanya hak dan kewajiban yang sama antar sesama manusia

d. Pembinaan yang berencana dan memiliki tujuan kedepannya dan terus di lakukan secara sistematis

Pendekatan yang di lakukan secara individual dan kolompok untuk mengetahui kebutuhan dan pola piker dari narapidana tersebut.

\section{PENUTUP}

Indonesia sebagai negara hukum dalam hal ini harus menerapkan pola hukum yang baik yang dituju tinggi yang namanya keadilan ya ini bisa dilihat di Pemasyarakatan yang di mana harus bisa menerapkan perlakuan dan perawatan yang baik kepada narapidana serta tahanan usia lanjut dengan menerapkan suatu konsep yang harus sesuai dengan peraturan dari segi gerontologi yang ada dalam pemeliharaan dan peningkatan derajat kesehatan terutama dalam perawatan Terhadap narapidana dan tahanan Lanjut Usia, sehingga hal tersebut dapat mendorong dan menjadi acuan kelam menjadikan pelopor terbentuknya peraturan yang berstandar internasional. sebagai petugas Pemasyarakatan kita harus sadar akan pentingnya HAM di dalam menerapkan suatu perilaku dan perlakuan khusus Terhadap 
narapidana dan tahanan Lanjut Usia. Perlakuan khusus atau membeda-bedakan Bukannya tidak adil tetapi dilihat dari sudut pandang lain perlakuan khusus harus diberikan, semua kembali pada HAM setiap manusia kebutuhan setiap individu itu berbeda sesuai kebutuhannya. Karena karena perlakuan keadilan bukan semata-mata perlakuan yang sama rata antara setiap individu dengan individu satunya namun esensi dari kebutuhannya.

Didalam Permenkumham Nomor 32 Tahun 2018 tentang Perlakuan Bagi Tahanan dan Narapidana Lanjut Usia secara umum sudah menjadi acuan dalam memberikan pembinaan, perawatan, dan perlakuan khusus bagi tahanan dan narapidana lanjut usia, meskipun demikian norma-norma yang ada intervensi sudah terkandung di dalam perlakuan tersebut, tetapi belum sepenuhnya semua selaras dengan berbagai instrumen terhadap HAM yang terkandung di dalam DUHAM.

Penelitian ini harus terus disempurnakan dan dikembangkan mengingat perspektif gerontologi ini juga terus berkembang seiring berkembangnya waktu dan zaman, lingkungan dan kebutuhan pun dapat berubah sewaktu waktu dan tidak kita sadari. Petugas Pemasyarakatan turut serta bertindak dan bertanggung jawab atas terlaksananya perlakuan dan pembinaan khusus bagi narapidana lanjut usia yang menjalani pembinaan di Lembaga Pemasayarakatan.

Perwataran dan Perlakuan yang diberikan kepada WBP khusus seperti usia lanjut oleh para petugas pemasyarakatan didalam menerapkan proses gerontology harus memperhatikan hal hal sebagai berikut:

(a) Diperlukan peraturan atau kebijakan yang lebih kuat dalam kekuatan hukumnya dan lebih ketat serta lebih tinggi kedudukannya dalam status hukumnya da siapa yang mengeluarkannya.

(b) Saat ketika seseorang sudah memasuki usia yang lanjut harus dilakukan tinjauan atau pemeriksaan akan keadaan fisik dan mental psikologis terutama kondis metal dari narapidanan dan tahana tersebut agar narapidana lanjut usia dapat acuan atau contoh dalam memberikan intervensi yang baik bagi narapidana dan tahanan lanjut usia dengan melihat dari sudut pandang perspektif gerontologi;

(c) Pemberlakuan pemisahan pada blok yang di huni menjadi hal yang harus diperhatikann terhadap narapidana usia lanjut disebabkan oleh kegiatan dan aktifitas intervensi yang diberikan terpaksa harus terpisah antara narapidanan dewasa dengan narapidana lanjut usia dengan kegiatan an aktifitas intervensiyang diberikan terhadap narapidana lainnya sehingga dalam prosespembinan dan perawatan dapat berjalan baik. Proses intervensi yang dilakukan harus dilaksanakan oleh tenaga professional dan tenagan yang sudah berkompeten serta ahli dalam bidangnya sehingga instrument HAM yang akan diberikan dapat tercaai sesuai tujuan awal dan sesuai dengan kebutuhan narapidanan lanjut usia tersebut. Tak luput juga harus adanya pelatihan khusus bagi petugas pemasyarakatan dalam menjalankan dan melaksanakan perlakuan dan perawatan terhadap narapidanan lanjut usia dengan melihat nilai nilai dari innstrumen yang sesuai dengan presektif HAM dan nilai nilai gerontology.

(d) Dari hal ini dapat di harapkan karakteristik dan intervensi terhadap narapidana lanjut usia di lembaga pemasyarakatan, Pihak instansi atau pihak lapas dapat menerapkan pembinaan dan perawatan yang sesuai dengan standard an kebutuhan bagi narapidana lanjut usia di lembaga pemasyarakatan tersebut, pembinaan yang ada bisa berupa pembinaan kemandirian dan kepribadian yang kedepannya akan menajadi sebuah inovasi yang baru dan akan berpengaruh dalam hasil pembinaan yang lebih optimal dan lebih efisien

\section{DAFTAR PUSTAKA}

\section{Artikel Jurnal}

Barus Brema Jaya Putranta, Biafri Vivi Sylvia. 2020. Pembinaan Kemandirian Terhadap Narapidana Lansia di Lapas Kelas I Medan. Jurnal Ilmu Pengetahuan Sosial. 7(1). 
Kurniyawan Antok. 2020. Jakarta Statmen Menuju Jakarta Rules : Strategi Melindungi Hak Napi Lansia. Jurnal HAM. 11(1).

Alamanzo Andrew Charlos. 2017. Pelaksanaan Pendidikandan Pengajaran Bagi Tahanan Sebagai bagian Program Perawataan Tahanan Di Kepolisian Resor Kota Bandar Lampung. Jurnal hokum.

Wulandari Sri. 2012. Efektifitas Sistem Pembinaan Narapidana Di Lembaga Pemasyarakatan

Mardiana, Naping Hamka, dan Hajar Abdul. 2012. Implementasi Sistem Pembinaan Narapidana Di lembaga Pemasyarakatan Klas II A Palu. Jurnal UNHAS

Bangun, Yosafat Ilias Adiguna. 2014. Efektifitas Pembinaan Di Lapas Kelas IIB Cebongan Sleman Yogyakarta. Jurnal HK

Kiik Stefanus Mendes. Junaiti Sahar, Henny Permatasari. 2018. Peningkatan Kualitas Hidup Lansia di Kota Depok Dengan Latihan Keseimbangan. Jurnal Keperawatan Inonesia. 21(2).

Prabasari P Ninda Ayu , Linda Juwita, Ira Ayu Maryuti. 2017. Pengalaman Keluarga Dalam Perawat Lansia Dirumah. Jurnal Ners Lentera. 5(1).

Sauself Cindi Kleri Romania. 2018. Pelaksanaan Pembinaan Narapidana Lansia Di Lembaga Pemasyarakataan KelasII Mataram. Jurnal Unram.

Hermasnyah, Masyitoh. Pemenuhan Hak Narapidana Lanjut Usia Bidang Kesehataan Di Lapas Kelas IIA Banda Aceh. Law Jurnal. 4(1).

Masura Ibnu, Padmono Wibowo. 2020. Pelayanan Khusus Warga Bianaan Lansia Menurut Permenkumham Ri 32 Tahun 2018 tentang Perlakuan Bagi Tahanan Dan Narapidanan Lansia. Jurnal Gema Keadilan. 7(3).

Pradipta I Wayan Diva Adi, Sukadana I Ketut, Karma Ni Made Sukaryati. 2020. Pembinaan Terhadap Narapidana Lansia di Lapas Kelas IIA Denpasar. Jurnal Analogi Hukum. 2(2).

\section{Website}

Info_Pas. 2019. The Jakarta Statement Menuju Standart Internasional Perlakuan Narapidanan Lansia. Diambil Febuari 20, 2021, Dari _http://ditjenpas.go.id/thejakarta-statement-menuju-standar-international-perlakuan-narapidana-lansia

ICJR. 2019. ICJR Dorong Pemerintah agar Skema Pemidanaan terhdapa Napi Lansia Diubah. Diambil Febuari 20, 2021, Dari https://icjr.or.id/icjr-dorong-pemerintah-agarskema-pemidanaan-terhadap-napi-lansia-diubah/

\section{Peraturan}

UU No 12 Tahun 1995

UU No 13 Tahun 1998

UU No 36 Tahun 2009

Permenkumham No 32 Tahun 2018

Permenkumham No 40 Tahun 2017

Permensos No 05 Tahun 2018

Permenkes No 73 Tahun 2013 